\title{
SACROPELVIC FIXATION USING ILIAC SCREWS: EVALUATION OF TECHNIQUE AND COMPLICATIONS
}

\author{
FIXAÇÃO SACROPÉLVICA COM USO DE PARAFUSOS ILÍACOS: AVALIAÇÃO DA TÉCNICA \\ E COMPLICAÇÕES
}

\section{FIJACIÓN SACROPÉLVICA CON USO DE TORNILLOS ILÍACOS: EVALUACIÓN DE LA TÉCNICA Y COMPLICACIONES}

\author{
Lendl do Vale Mendonça ${ }^{1}$, René Kusabara², Fabio Mastromauro de Oliveira ${ }^{2}$, Yoshinobu Nagasse² ${ }^{2}$ Iberê Ribeiro², Clóvis Yamazato², \\ Eduardo Soares de Souza \\ 1. Hospital Bandeirantes, Spine Service, São Paulo, SP, Brazil. \\ 2. Sociedade Brasileira de Coluna, São Paulo, SP, Brazil.
}

\begin{abstract}
Sacropelvic fixation arose from the need to protect the sacral instrumentation in long constructions, due to failures in the implant-bone interface and the treatment of diseases in which there is no possibilities of sacral fixation such as infections and tumors. Due to anatomic difficulties and the complex spinopelvic biomechanics several techniques were developed. The fixation with iliac screws has become according to multiple studies, a well-established technique that minimizes frequent complications such as pseudoarthrosis and implant failure. However, it has disadvantages such as iliac wing fracture and skin lesions due to the protrusion of materials. The present study aims to comprehensively review the literature on the technique taking into account relevant aspects to its better knowledge and application. Level of evidence III; Therapeutic Study.
\end{abstract}

Keywords: Lumbosacral region; Bone screws; Spinal fusion.

\section{RESUMO}

A fixação sacropélvica surgiu como uma necessidade de proteção à instrumentação sacral em construções longas, devido as falhas na interface implante- osso, e ao tratamento de doenças, nas quais não há possibilidades de fixação sacral, como infecções e tumores. Devido às dificuldades anatômicas e à complexa biomecânica espino-pélvica, diversas técnicas foram criadas. a fixação através de parafusos ilíacos se tornou, através de diversos estudos, uma técnica consagrada, minimizando complicações frequentes, como pseudoartrose e falha do implante. Porém, esta possui desvantagens, como fratura da asa do ilíaco e lesão cutânea decorrente de proeminência dos materiais. Esse estudo se destina a revisar, de uma forma abrangente, a literatura acerca da técnica, levando-se em consideração aspectos relevantes para o seu melhor conhecimento e aplicação. Nível de Evidência III; Estudo Terapêutico.

Descritores: Região lombossacral; Parafusos ósseos; Fusão vertebral.

\section{RESUMEN}

La fijación sacropélvica surgió como una necesidad de proteger la instrumentación del sacro en construcciones largas, debido a fallas en la interfaz implante-hueso y al tratamiento de enfermedades en las que no hay posibilidades de fijación del sacro, como infecciones y tumores. Debido a las dificultades anatómicas y a la compleja biomecánica espinopélvica, se desarrollaron varias técnicas. La fijación con tornillos ilíacos se ha convertido, de acuerdo con diversos estudios, en una técnica bien establecida que minimiza complicaciones frecuentes como pseudoartrosis y falla del implante. Sin embargo, tiene desventajas, como fractura del ala ilíaca y lesiones de la piel debido a la prominencia de los materiales. Este estudio se destina a revisar de forma amplia la literatura acerca de la técnica, teniendo en cuenta aspectos relevantes para su mejor conocimiento y aplicación. Nivel de evidencia III; Estudio Terapéutico.

Descriptores: Región lumbosacra; Tornillos óseos; Fusión vertebral.

\section{INTRODUCTION}

The first spinal instrumentation techniques developed for pelvic fixation date from the 1970s when Luque developed multiple sublaminar fixation using wires connected to a rod in the shape of an $\mathrm{L}$ to prevent its rotation. ${ }^{1}$ Later, in 1976, Allen and Ferguson described their experience with the Galveston technique. ${ }^{2}$ This technique involved the implantation of L-shaped rods, differentiated in their distal portion, anchored between the internal and external tables of the ilium. With advances in instrumentation and the development of fixation using Cotrel-Dubousset rods, sacropelvic fixation began to be performed using hooks and pedicle screws, ${ }^{2}$ implemented for the first time in 1973 by Vidal and later modified by Dubousset and Farcy. ${ }^{3}$

Despite the advances in surgical techniques, arthrodesis of the lumbosacral junction remains a challenge with high failure rates, mainly in cases that require treatment using long constructions. ${ }^{4}$ Several aspects contribute to the difficulty in successful treatment. The spinopelvic biomechanical complex generates high rates of 
pseudoarthrosis and bone implant failure, in addition to contributing to late complications such as flat back.

Given the increasing use of instrumentation to treat spinal pathologies and the difficulties faced in the case of sacropelvic fixation, the objective of this article is to review the iliac screw technique addressing general aspects and comparing it to other techniques.

\section{Applied anatomy}

The sacrum is the pivot of the spinopelvic junction, articulating with the last lumbar vertebra and the two iliac bones in their hemipelves to form the pelvis as a whole. It is comprised of five vertebrae and its dimensions range from $47 \mathrm{~mm}$ in S1 to $28 \mathrm{~mm}$ in $\mathrm{S} 2$ in the anterior posterior direction in women and from $50 \mathrm{~mm}$ in $\mathrm{S} 1$ and $31 \mathrm{~mm}$ in S2 in men. ${ }^{5}$ Formed mostly of spongy bone, its highest density is found in the regions of the promontory and wings. The measurements of the pedicle of S1, trapezoidal in shape and about $20 \mathrm{~mm}$ in the horizontal plane and 25 to $30 \mathrm{~mm}$ in the vertical plane, are also significant. ${ }^{4}$ The sacrum has a relationship with several important vascular and neurological structures, which must be considered when inserting screws. ${ }^{5}$

In his study on sacral fixation, Arlet $^{4}$ cites the ilium as the only pelvic fixation point that allows screw insertion anteriorly to the center of the osteoligamentous spine. Furthermore, he compares the ilium to a long bone with a diaphyseal portion anteriorly delimited by the head of the acetabulum and the anterior inferior iliac spine and posteriorly by the portion between the two posterior iliac spines. This diaphyseal region has an average height of $32.1 \mathrm{~mm}$ and an average distance between the anterior posterior iliac crest and the ischiatic notch of $70.8 \mathrm{~mm} .{ }^{4}$ The thickness of the posterior superior iliac spine ranges from $35 \mathrm{~mm}$ at the S2 level to $17 \mathrm{~mm}$ at the S1 level. ${ }^{4}$ These measurements are important in planning and in the sizing of the implants to be used.

An important concept was introduced by O'Brien ${ }^{6}$ when he divided the sacrum and the pelvis into 3 zones from an anatomical and instrumentation-related perspective. Zone 1 is formed by the body of $\mathrm{S} 1$ and the cephalic portion of the sacral wing. Zone 2 includes the sacral wing and extends to S5. Zone 3 includes both sides of the ilium (Figures $1 \mathrm{~A}-\mathrm{B}$ ).

\section{Biomechanics}

Several studies of the sacropelvic biomechanical complex have been conducted with the goal of determining which technique would have better arthrodesis rates and fewer implant failures., ${ }^{3,-14}$ The authors of these studies submitted the assemblies to moments of flexion and established several important concepts such as the pivot point. Maccord, ${ }^{7}$ in his biomechanical analysis of lumbosacral fixation, demonstrated that the maximum bending moment was significantly greater in those devices if they extended to the ilium.
In the same study, he arrived at the concept of the pivot point, which is the lumbosacral transition, an intersection between the middle osteoligamentous spine in the sagittal plane and the L5-S1 intervertebral disc in the transverse plane. It was concluded that the stability of pelvic fixations was greater in instrumentations anterior to the pivot point, such as iliac screws.

In another biomechanical analysis study, Perrault ${ }^{15}$ showed that both a shorter lateral connector length and the use of intrarod connectors decrease the force and the torque on the iliac screw.

\section{Indications}

There are several indications for sacropelvic fixation: high-grade spondylolisthesis, ${ }^{16-18}$ unstable sacral fractures, sacral tumors, and insufficiency failures. ${ }^{19,20}$ However, according to Shen, ${ }^{2}$ the most common indication for pelvic fixation is the correction of deformities in adult patients. Another relevant reason is fixation in patients with neuromuscular scoliosis due to optimal correction in the sagittal plane and of pelvic inclination. ${ }^{21}$ In general, in any patient who needs a construction that begins in the sacrum and extends to L2 or more proximally, the extension of the fixation to the pelvis will be important; just as in those patients with a significant deformity of the coronal and sagittal planes, where there is a chance of evolution into kyphosis of level L5-S1 following instrumentation, due to the high pull-out forces suffered by the system, implying the failure of the implant. ${ }^{2}$ Other indications also apply to patients with osteoporosis or those who undergo sacrectomy. ${ }^{20}$

Associated contraindications include patients with previously altered or impaired anatomy due to pathology that prevent secure pelvic fixation. It should be noted that the collection of graft material in the iliac region does not impede pelvic fixation. ${ }^{18}$

\section{Technique}

The acknowledged technique for the placement of iliac screws consists of the exposure of the posterior superior iliac spine with preparation of the point of entry and passage of the probe in the direction of the anterior inferior iliac spine (AIIS) at a caudal inclination of from 20-45 degrees and a lateral inclination of 30-45 degrees. ${ }^{2}$ Dissection up to the ischiatic notch is performed to prevent its perforation. The point of entry can vary according to some authors: situated about $2.4 \mathrm{~cm}$ above the AllS to establish the best anchor point for the screw ${ }^{22}$ or below the AlIS when the goal is to place more than one screw in the ilium. ${ }^{23}$ In his anatomical and radiological study, Schildhauer ${ }^{24}$ found an average PSIS-AllS trajectory length of $141 \mathrm{~mm}$ in men and $129 \mathrm{~mm}$ in women and a possible accommodation of implants of $8 \mathrm{~mm}$ in diameter in men and 6-7 $\mathrm{mm}$ in women.

Other screw paths have also been studied to confirm the best positioning from a biomechanical and radiological perspective. In addition to the path in the direction of the AlIS, the trajectory in

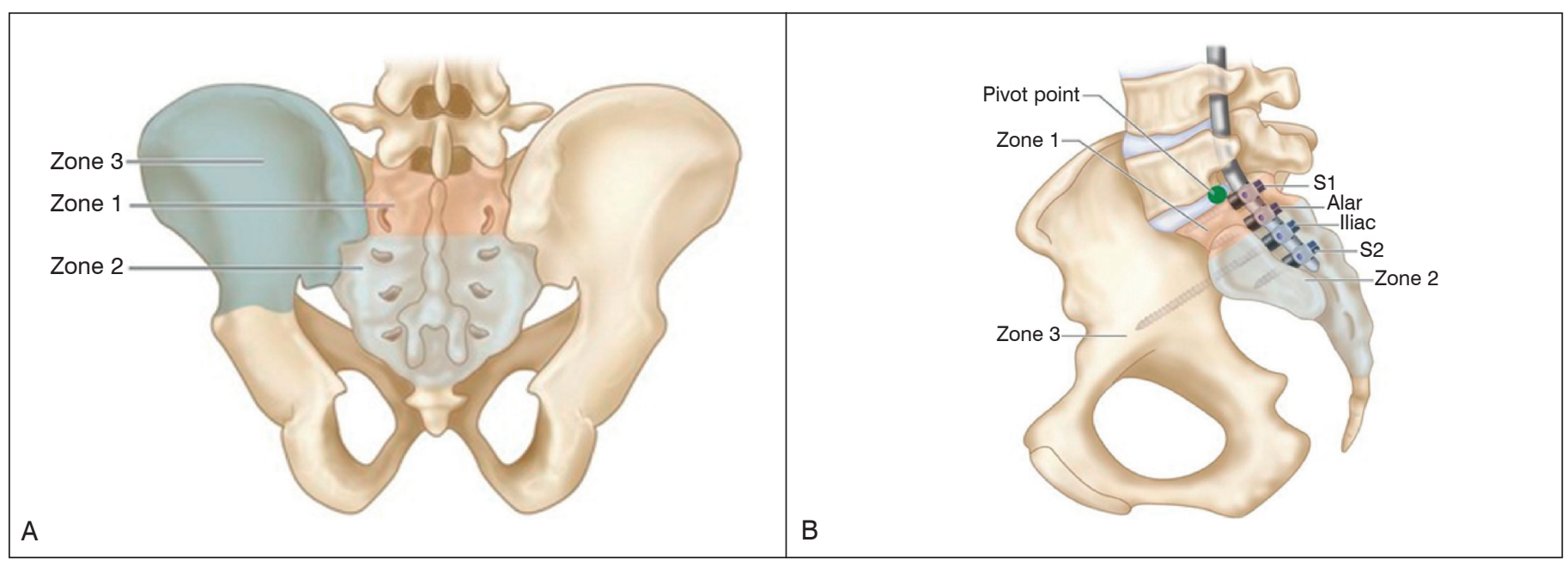

Figure 1. A) Coronal view of the pelvis showing the O'Brien zones; B) Sagittal pelvic view showing the types of lumbosacral fixation in relation to the O'Brien zones. 
the direction of the supra-acetabular region also has shown to be a good alternative, accommodating the screw and high torque. ${ }^{19}$ Santos $^{19}$ studied the length, diameter, and best trajectory for the iliac screw, arriving at the conclusion that whether the screw was directed towards the AllS or towards the supra-acetabular region, the important factor was the depth of the screw, demonstrating the highest resistance at lengths above $80 \mathrm{~mm}$ and with a diameter of $9 \mathrm{~mm}$. It was proven that the great disadvantage in the approach towards the acetabular roof was the risk of impingement. ${ }^{25}$

To avoid increases in surgical time and bleeding several free-hand or scope-guided techniques emerged. ${ }^{26}$ Fridley $^{27}$ developed a safe approach for the insertion of iliac screws using the superior edge of the lamina and the spinous process of $L 5$ as anatomical parameters. (Figure 2) Other studies say that the best fixation involves two screws in each hemipelvis in patients with neuromuscular scoliosis ${ }^{7}$ and talk about the importance of larger diameter screws in lieu of longer screws in cases of iliac fixation revision. ${ }^{28}$ In his study of sacropelvic fixation revision, Kebaish ${ }^{29}$ describes a technique using an S2 alar iliac screw with the $\mathrm{S} 1$ foramen as the starting point, 2 to $4 \mathrm{~mm}$ laterally and 4 to $8 \mathrm{~mm}$ distally, advancing into the iliac crest in the direction of the ischiatic notch, which permits the placement of long, large-diameter pelvic screws without the prominence of the PSIS starting point.

To confirm the position of the screw without submitting the patient to dissection that would increase surgical time and bleeding, Orchowski ${ }^{30}$ conducted a study using the fluoroscope and established the following relationships: the Judet obturator oblique position was used to evaluate the ischiatic notch; inlet and outlet views were used to evaluate the acetabulum; and the Judet oblique iliac incidence was used to evaluate the integrity of the medial cortex of the ilium.

\section{Comparative analysis}

There are several comparative studies of sacropelvic fixation techniques, most of which compare the Galveston technique with that using bilateral iliac screws, even though the principal is the same. Rudt, ${ }^{5}$ for example, concluded that iliac screws are easier to place, they offer the possibility of using more than one screw in each ilium, and anchoring in the bone is more efficient and offers greater resistance to pull-out. Along the same lines, Ernami ${ }^{12}$ observed high rates of pseudoarthrosis using the Galveston fixation in the correction of adult spinal deformities and Peelle ${ }^{13}$ reported complications resulting from the difficult modeling of rods to fit the iliac curves. In specific cases, such as sacrectomy, better outcomes were also demonstrated with iliac screws. ${ }^{31}$

Other studies also compared the results with iliosacral plates ${ }^{14}$ and L5-S1 grafts associated with sacral fixation, ${ }^{11}$ but the iliac screws are still more efficient.

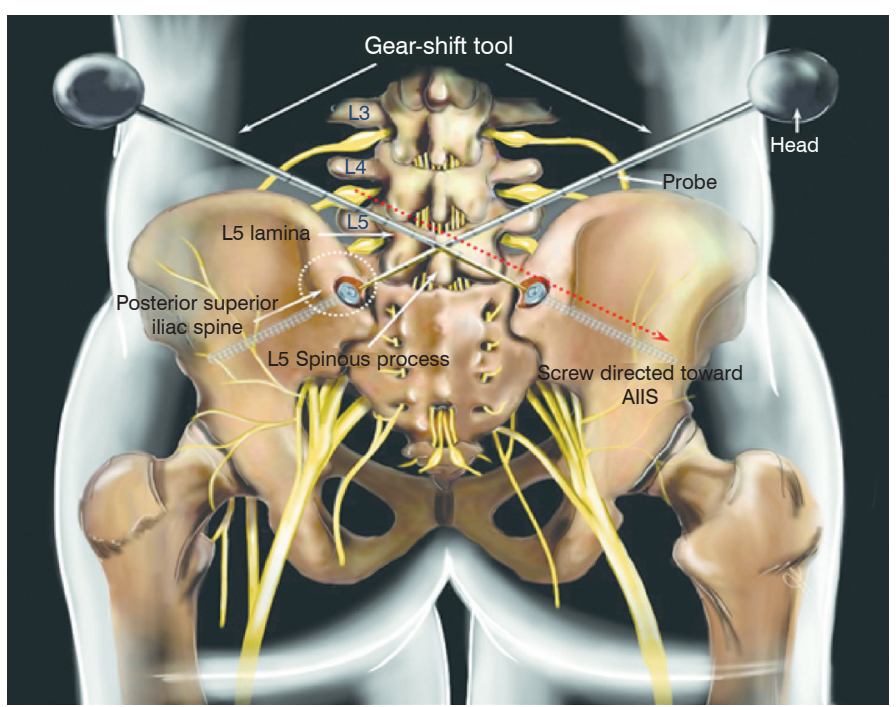

Figure 2. Representative diagram with the anatomical parameters for the placement of iliac screws using the "free-hand" technique proposed by Fridley.
A new method that has had good outcomes with iliac screws is implantation through the S2 alar iliac technique. ${ }^{2}$ Ilyas, ${ }^{32}$ in a study in which early clinical radiographical complications from this technique in an adult and pediatric population reported encouraging data related to low rates of complications, such as loosening of the implant, late pain, surgical revision, acute infection, and persistent wounds. Chang ${ }^{9}$ compared the anatomical parameters of the two fixations and reported the fact that the point of implantation of the S2 alar iliac screws is deeper, reducing complications related to the prominence of the implant. However, a disadvantage of this method is the risk of violation of the ischiatic notch from the use of longer screws, and of the sacroiliac joint, without having any knowledge of the long-term clinical consequences. ${ }^{27}$

\section{Complications}

In his article on middle-term follow-up, Hyun ${ }^{33}$ described well the complications encountered with the use of iliac screws: blood loss, postoperative infection, peri-implant halos, injury to structures like the ischiatic notch and the acetabulum, and prominence of the material.

Significant bleeding is expected in this procedure due to the need for extensive dissection, aggravated in those techniques that use direct visualization of the ischiatic notch. Blood loss greater than $5000 \mathrm{ml}$ was observed following vertebral decortication. ${ }^{33}$ An $8 \%$ infection rate was found by Phillips ${ }^{21}$ in treating patients with neuromuscular scoliosis. Rudt ${ }^{5}$ observed $4 \%$ infection in his sample in sacropelvic fixation in adults. It is appropriate to discuss whether the pathology influenced the difference observed in rates of infection, even though the samples in the two studies were small.

Pseudoarthrosis is certainly the most worrisome complication because it is directly related to the effectiveness of the technique. In follow-up studies with samples of 67 and 81 patients, Tsuchiya ${ }^{16}$ and $\mathrm{Kuklo}^{18}$ reported pseudoarthrosis rates of $7.4 \%$ and $4.9 \%$, respectively. However, it should be noted that, in the two studies, the rates were less than those in groups where there was an association with previous devices in L4-S1.

Discomfort, pain, and wounds caused by the prominence of screws in the sacral region were routine complications encountered in the various studies about the use of the technique. 5,16,18,33,34 Kasten ${ }^{34}$ reported the removal of iliac screws in 6 out of 78 patients, around $7.7 \%$, because of complaints of local pain. Halos around the iliac screws are common, but they do not necessarily have any influence on the assessment of lumbosacral fusion, ${ }^{32}$ unlike breakage of the material (rod, screw, or connector), a sign of prodromal pseudoarthrosis. Cabada ${ }^{35}$ reported $31.8 \%$ of rod breakage at the lumbosacral level in his follow-up study of sacropelvic fixation in scoliosis. He reported an interesting relationship regarding age and walking ability, showing with statistical significance that those patients younger than 17 years of age or unable to walk had a lower implant failure rate, but he did not observe significance between the two associated characteristics.

\section{CONCLUSION}

In general, the acceptance of the sacropelvic fixation technique using iliac screws is well-known. As an evolution of the Galveston technique, it has a biomechanical backing that makes it effective with low rates of pseudoarthrosis. It is obvious that, as a technique with good results and wide use, it has undergone variations aimed at improvement and the minimization of complications. Among these improvements, the use of scopes and studies of free-hand techniques have lowered the risks of violation of spaces like the ischiatic notch and the acetabulum, in addition to reducing surgical time and bleeding, avoiding infections. It is also important to highlight the different variations of the point of entry of the screw aimed at providing more comfort to patients by reducing its prominence. This has made the iliac screw technique efficient and safe for use in various pathologies that require sacropelvic fixation.

All authors declare no potential conflict of interest related to this article. 
CONTRIBUTION OF THE AUTHORS: Each author made significant individual contributions to this manuscript. LVM (0000-0001-7564-7413)*, RK $(0000-0003-2673-7193)^{\star}$, and FMO (0000-0002-5217-1210)* were the main contributors to the writing of the manuscript. YN (0000-0003-0708-2961)*, IB $(0000-0003-2430-4466)^{\star}$, CY (0000-0001-7920-7634)*, and ESS (0000-0001-9529-4731)* participated in the bibliographical research, the manuscript review, and they contributed to the intellectual concept of the study. ${ }^{\star}$ ORCID (Open Researcher and Contributor ID).

\section{REFERENCES}

1. Luque ER. The anatomic basis and development of segmental spinal instrumentation Spine (Phila Pa 1976). 1982;7(3):256-9.

2. Shen FH, Mason JR, Shimer AL, Arlet VM. Pelvic fixation for adult scoliosis. Eur Spine J. 2013:22(Suppl 2):265-75.

3. Kostuik JP. Spinopelvic fixation. Neurol India. 2005;53(4):483-8

4. Arlet V, Ouellet J, Vialle E. Técnicas de fixação da coluna lombossacral. Rev Coluna/Columna. 2003;2(1):11-9.

5. Rudt T, Zisuela RG, Kahl G, Santi M. Fijación espinopélvica en el adulto. Criterios de selección. Rev Coluna/Columna. 2012;11(2):160-1.

6. Garcia GVO, Soto RO, Uribe EV, Avila JMJ. Lumbopelvic fixation: a surgical alternative for lumbar stability. Rev Coluna/Columna. 2014;13(3):219-22.

7. McCord DH, Cunningham BW, Shono Y, Myers JJ, McAfee PC. Biomechanical analysis of lumbosacral fixation. Spine (Phila Pa 1976). 1992;17(8 Suppl):235-43.

8. Saigal R, Lau D, Wadhwa R, Le H, Khashan M, Berven S, et al. Unilateral versus bilateral iliac screws for spinopelvic fixation: are two screws better than one? Neurosurg Focus. 2014;36(5):E10.

9. Chang TL, Sponseller PD, Kebaish KM, Fishman EK. Low profile pelvic fixation: anatomic parameters for sacral alar-iliac fixation versus tradicional iliac fixation. Spine (Phila Pa 1976). 2009;34(5):436-40

10. Kim JH, Horton W HamasakiT, Freedman B, Whitesides TE, Hutton WC Spinal instrumentation for sacral-pelvic fixation: a biomechanical comparison between constructs ending with either S2 bicortical, bitriangulated screws or iliac screws. J Spinal Disord Tech. 2010;23(8):506-12.

11. Cunningham BW, Sefter JC, Hu N, Kim SW, Bridwell KH, McAfee PC. Biomechanical comparison of iliac screws versus interbody femoral ring allograft on lumbosacral kinematics and sacral screw strain. Spine (Phila Pa 1976). 2010;35(6):198-205.

12. Emami A, Deviren V, Berven S, Smith JA, Hu SS, Bradford DS. Outcome and complications of long fusions to the sacrum in adult spine deformity: LuqueGalveston, combined iliac and sacral screws, and sacral fixation. Spine (Phila pa 1976). 2002;27(7):776-86

13. Peelle MW, Lenke LG, Bridwell KH, Sides B. Comparison of pelvic fixation techniques in neuromuscular spinal deformity correction: Galveston rod versus iliac and lumbosacral screws. Spine (Phila Pa 1976). 2006;31(20):2392-8.

14. FingerT, Bayerl S, Onken J, Czabanka M, Woitzik J, Vajkoczy P. Sacropelvic fixation versus fusion to the sacrum for spondylodesis in multilevel degenerative spine disease. Eur Spine J. 2014;23(5):1013-20.

15. Perrault FD, Aubin CE, Wang X, Schwend RM. Biomechanical analysis of forces sustained by iliac screws in spinal instrumentation for deformity treatment: preliminary results. Stud Health Technol Inform. 2012;176:307-10.

16. Tsuchiya K, Bridwell KH, KukloTR, Lenke LG, Baldus C. Minimum 5-year analysis of L5-S1 fusion using sacropelvic fixation (bilateral S1 and iliac screws) for spinal deformity. Spine (Phila Pa 1976). 2006;31(3):303-8.

17. Bridwell $\mathrm{KH}$. Utilization of iliac screws and structural interbody grafting for revision spondylolisthesis surgery. Spine (Phila Pa 1976). 2005;30(6 Suppl):88-96.

18. Kuklo TR, Bridwell KH, Lewis SJ, Baldus C, Blanke K, Iffrig TM, et al. Minimum 2-year analysis of sacropelvic fixation and L5-S1 fusion using S1 and iliac screws. Spine (Phila Pa 1976). 2001;26(18):1976-83.
19. Santos ER, Sembrano JN, Mueller B, Polly DW. Optimizing iliac screw fixation: a biomechanical study on screw length, trajectory, and diameter. J Neurosurg Spine. $2011 ; 14(2): 219-25$

20. Tumialán LM, Mummaneni PV. Long-segment spinal fixation using pelvic screws. Neurosurgery. 2008;63(3 Suppl):183-90.

21. Phillips JH, Gutheil JP, Knapp DR. Iliac screw fixation in neuromuscular scoliosis. Spine (Phila Pa 1976). 2007;32(14):1566-70.

22. Liu B, Wang J, Zhang L, Gan W. Radiographic study of iliac screw passages. J Orthop Surg Res. 2014;9:40.

23. Yu BS, Zhuang XM, Zheng ZM, Li ZM, Wang TP, Lu WW. Biomechanical advantages of dual over single iliac screws in lumbo-iliac fixation construct. Eur Spine J. 2010;19(7):1121-8

24. Schildhauer TA, McCulloch P, Chapman JR, Mann FA. Anatomic and radiographic considerations for placement of transiliac screws in lumbopelvic fixations. J Spinal Disord Tech. 2002;15(3):199-205.

25. Liu B, Zhang LY, Wang JW, Weil YS, Lin LM. [CT radiographic study of different paths of iliac screw path]. Zhongguo Gu Shang. 2011;24(2):141-4

26. Shin JH, Hoh DJ, Kalfas IH. Iliac screw fixation using computer-assisted computer tomographic image guidance: technical note. Neurosurgery. 2012;70(1 Suppl Operative): $16-20$

27. Fridley J, Fahim D, Navarro J, Wolinsky JP, Omeis I. Free-hand placement of iliac screws for spinopelvic fixation based on anatomical landmarks: technical note. Int J Spine Surg. 2014;8:3.

28. Akesen B, Wu C, Mehbod AA, Sokolowski M. Transfeldt EE. Revision of loosened iliac screws: a biomechanical study of longer and bigger screws. Spine (Phila Pa 1976). 2008; 33(13):1423-8.

29. Kebaish KM. Sacropelvic fixation: techniques and complications. Spine (Phila Pa 1976). 2010;35(25):2245-51

30. Orchowski JR, Polly DW, Kuklo TR, Klemme WR, Schroeder TM. Use of fluoroscopy to evaluate iliac screw position. Am J Orthop (Belle Mead NJ). 2006;35(3):144-6.

31. Mindea SA, Chinthakunta S, Moldavsky M, Gudipally M, Khalil S. Biomechanical comparison of spinopelvic reconstruction techniques in the setting of total sacrectomy. Spine (Phila Pa 1976). 2012;37(26):E1622-7.

32. Ilyas H, Place H, Puryear A. A Comparison of Early Clinical and Radiographic Complications of Iliac Screw Fixation Versus S2 Alar Iliac (S2AI) Fixation in the Adult and Pediatric Populations. J Spinal Disord Tech. 2015;28(4):E199205.

33. Hyun SJ, Rhim SC, Kim YJ, Kim YB. A mid-term follow-up result of spinopelvic fixation using iliac screws for lumbosacral fusion. J Korean Neurosurg Soc. 2010;48(4):347-53.

34. Kasten MD, Rao LA, Priest B. Long-term results of iliac wing fixation below extensive fusions in ambulatory adult patients with spinal disorders. J Spinal Disord Tech. 2010;23(7):e37-42.

35. Cabada CE, Burgos J, Barrios C, Vera P, Hevia E, Sanpera I, et al. Resultado a largo plazo de las fusiones largas espinopelvicas en escoliosis: importancia de la edad, la capacidad de marcha y el tipo de fijación ilíaca. Rev Coluna/ Columna. 2013;12(4):285-90. 